\title{
RETRACTED ARTICLE: Association of insulin-like growth factor 1 receptor and estrogen receptor with pathological complete response to neoadjuvant chemotherapy in HER2-negative breast cancer
}

\author{
Lei Liu ${ }^{1}$ Y Yunhui Hu${ }^{1}$. Sheng Zhang ${ }^{1} \cdot$ Xiru Li ${ }^{2}$ Jin Zhang ${ }^{1}$ \\ Received: 2 April 2018 / Accepted: 26 November 2018 / Published online: 8 January 2019 \\ (C) The Author(s) 2019
}

The Editor-in-Chief has retracted this article [1] because, contrary to the statement in the article, the authors have been unable to provide documents confirming that ethics approval was obtained for the study. The ethics committee of Tianjin Medical University Cancer Institute and Hospital has confirmed that it did not approve this study. All authors agree to this retraction.

OpenAccess This article is distributed under the terms of the Creative Commons Attribution 4.0 International License (http://creativeco mmons.org/licenses/by/4.0/), which permits unrestricted use, distribution, and reproduction in any medium, provided you give appropriate credit to the original author(s) and the source, provide a link to the Creative Commons license, and indicate if changes were made.

Electronic supplementary material The online version of this article (https://doi.org/10.1007/s12282-018-00939-y) contains supplementary material, which is available to authorized users.

Xiru Li

24681i@sina.com

$\bowtie$ Jin Zhang

zhangjin@tjmuch.com

1 The Third Department of Breast Cancer, China Tianjin Breast Cancer Prevention, Treatment and Research Center, Tianjin Medical University Cancer Institute and Hospital, National Clinical Research Center of Cancer, Huanhu West Road, Tianjin 300000, China

2 Department of Surgery, Chinese PLA General Hospital, No.28 Fuxing Road, Beijing 100071, China

\section{Reference}

1. Liu L, Hu Y, Zhang S, et al. Association of insulin-like growth factor 1 receptor and estrogen receptor with pathological complete response to neoadjuvant chemotherapy in HER2-negative breast cancer. Breast Cancer. 2019. https://doi.org/10.1007/s12282-01800939-y. 